\title{
Iron oxide nanoparticles induce human microvascular endothelial cell permeability through reactive oxygen species production and microtubule remodeling
}

\author{
Patrick L Apopa1,2, Yong Qian*1, Rong Shao ${ }^{3}$, Nancy Lan Guo ${ }^{4}$, \\ Diane Schwegler-Berry ${ }^{1}$, Maricica Pacurari ${ }^{1}$, Dale Porter ${ }^{1}{ }^{5}$, Xianglin Shi ${ }^{1}$, \\ Val Vallyathan ${ }^{1}$, Vincent Castranova ${ }^{1}$ and Daniel C Flynn*6
}

\begin{abstract}
Address: ${ }^{1}$ The Pathology and Physiology Research Branch, Health Effects Laboratory Division, National Institute for Occupational Safety and Health, Morgantown, WV 26505, USA, ${ }^{2}$ MBR Cancer Center, School of Medicine, West Virginia University, Morgantown, WV 26506-9300, USA, ${ }^{3}$ Pioneer Valley Life Sciences Institute, Baystate Medical Center/University of Massachusetts at Amherst, Springfield, MA 01107, USA, ${ }^{4}$ MBR Cancer Center/Department of Community Medicine, School of Medicine, West Virginia University, Morgantown, WV 26506-9300, USA, 5Department of Physiology and Pharmacology, School of Medicine, West Virginia University, Morgantown, WV 26506, USA and ${ }^{6}$ The Commonwealth Medical College, Scranton, PA 18510, USA

Email: Patrick L Apopa - papopa@cdc.gov; Yong Qian* - yqian@cdc.gov; Rong Shao - yqian@cdc.gov; Nancy Lan Guo - lguo@hsc.wvu.edu; Diane Schwegler-Berry - dschwegler-berry@cdc.gov; Maricica Pacurari - mpacurari@cdc.gov; Dale Porter - dporter@cdc.gov;

Xianglin Shi - xshi@cdc.gov; Val Vallyathan - vvallyathan@cdc.gov; Vincent Castranova - vcastranova@cdc.gov;

Daniel C Flynn* - dflynn@hsc.wvu.edu

* Corresponding authors
\end{abstract}

Published: 9 January 2009

Particle and Fibre Toxicology 2009, 6:I doi:10.1 186/1743-8977-6-1
Received: 18 July 2008

Accepted: 9 January 2009

This article is available from: http://www.particleandfibretoxicology.com/content/6/I/I

(C) 2009 Apopa et al; licensee BioMed Central Ltd.

This is an Open Access article distributed under the terms of the Creative Commons Attribution License (http://creativecommons.org/licenses/by/2.0), which permits unrestricted use, distribution, and reproduction in any medium, provided the original work is properly cited.

\begin{abstract}
Background: Engineered iron nanoparticles are being explored for the development of biomedical applications and many other industry purposes. However, to date little is known concerning the precise mechanisms of translocation of iron nanoparticles into targeted tissues and organs from blood circulation, as well as the underlying implications of potential harmful health effects in human.

Results: The confocal microscopy imaging analysis demonstrates that exposure to engineered iron nanoparticles induces an increase in cell permeability in human microvascular endothelial cells. Our studies further reveal iron nanoparticles enhance the permeability through the production of reactive oxygen species (ROS) and the stabilization of microtubules. We also showed Akt/GSK-3 $\beta$ signaling pathways are involved in iron nanoparticle-induced cell permeability. The inhibition of ROS demonstrate ROS play a major role in regulating Akt/GSK-3 $\beta$ - mediated cell permeability upon iron nanoparticle exposure. These results provide new insights into the bioreactivity of engineered iron nanoparticles which can inform potential applications in medical imaging or drug delivery.
\end{abstract}

Conclusion: Our results indicate that exposure to iron nanoparticles induces an increase in endothelial cell permeability through ROS oxidative stress-modulated microtubule remodeling. The findings from this study provide new understandings on the effects of nanoparticles on vascular transport of macromolecules and drugs. 


\section{Background}

Iron nanoparticles are of great interest due to their unique physicochemical properties and have been used for the development of imaging, magnetic and electrical applications [1]. Recently, iron nanoparticles have been widely used in coal industry to produce clean fuels due to their catalytic activities that facilitate the chemical reactions to form and cleave carbon-carbon bonds [2]. More importantly, iron nanoparticles show great potential in human biomedical applications, such as labeling and magnetic separation of biological materials, imaging and diagnostic applications in human, site-directed drug delivery, and anticancer hyperthermia therapy [2]. However, significant knowledge gaps currently exist on the precise mechanisms of translocation of iron nanoparticles into the targeted tissues, organs, and tumors, as well as the toxicological effect of iron nanoparticles, which would deter their broad applications.

Endothelial cells play a central role in angiogenesis, carcinogenesis, atherosclerosis, myocardial infarction, limb and cardiac ischemia, and tumor growth $[3,4]$. The endothelium is an important target for drug and gene therapy. The vascular endothelial monolayer forms a semi-selective permeability barrier between blood and the interstitial space to control the movement of blood fluid, proteins, and macromolecules across the vessel wall. Alteration of permeability barrier integrity plays a major role in drug-based therapies, as well as the pathogenesis of cardiovascular diseases, inflammation, acute lung injury syndromes, and carcinogenesis $[3,5,6]$.

Several studies have shown that intravenously administrated iron nanoparticles can translocate from the blood circulation into various targeted tissues and organs $[1,7]$. However, it is not clear how iron nanoparticles cross the endothelium from the blood stream into the targeted sites. In this study, we sought to examine whether iron nanoparticle exposure would induce an increase in permeability in human microvascular endothelial cells (HMVECs) and to determine the underlying molecular mechanisms involved. Particular emphasis was focused on the involvements of iron nanoparticle-induced reactive oxygen species (ROS) production in endothelial cell permeability changes. The results in this report demonstrate that iron nanoparticle exposure induces an increase in permeability in HMVECs. This iron nanoparticleinduced permeability involves the production of ROS and the stabilization of microtubules. Furthermore, it was found that PI-3 kinase/Akt/GSK-3 $\beta$ pathways are the important mediators for iron nanoparticle-induced endothelial cell permeability. The results obtained from this study provide the evidence, for the first time, showing that iron nanoparticles may cross the endothelial monolayer through the induction of cell permeability. The results obtained from this study may also provide some insights for understanding the translocation pathways of nanoparticles in general.

\section{Results \\ Size distribution of nanoparticle in cell culture medium and uptake of iron nanoparticles by HMVECs}

Iron nanoparticles used in these experiments are ferrites of maghemite $\left(\mathrm{Fe}_{2} \mathrm{O}_{3}\right)$, which are superparamagnetic nanoparticles. Unmodified nanoparticles are usually colloidal in nature and prone to agglomerate in suspension [8]. In order to accurately measure the size and distribution of iron nanoparticles in aqueous solutions, a TEM was applied to profile iron nanoparticles in $0.1 \%$ FBS cell culture medium. As shown in Figure 1A, the nanoparticles ranged in size from $50 \mathrm{~nm}-600 \mathrm{~nm}$. Since a TEM can only measure very limited number of particles in solution and the particles subjected to measurements are fixed and dried, it may not provide an accurate profile of the particles in the working solution. Therefore, we applied a dynamic light scattering (DLS) measurement to further characterize the particle size in the working solution. These measurement results showed that iron nanoparticles existed in a size range from $100 \mathrm{~nm}-700 \mathrm{~nm}$ with a mean diameter of $298 \mathrm{~nm}$ (Figure 1B). These results demonstrate that iron nanoparticles form small agglomerates, which are uniformly distributed in cell culture medium.

Previously, it was shown that iron nanoparticles can be taken up by mouse macrophages in vivo [9] and rat pheochromocytoma cell line (PC12M) in vitro [10]. Here, we investigated the uptake of iron nanoparticles by HMVECs. The HMVEC line used here was immortalized by engineering human telomerase catalytic protein (hTERT) into the cells and are therefore able to maintain the inherent features of primary endothelial cells [11]. The cells were cultured to a confluent monolayer on transwell tissue culture-treated polycarbonate membrane polystyrene plates (Corning, NY), and then were stimulated with $50 \mu \mathrm{g} / \mathrm{ml}$ iron nanoparticles for different periods of time ranging from $10 \mathrm{~min}$ to $5 \mathrm{~h}$. After the stimulation, the cells were processed for TEM analysis. As shown in figure $1 \mathrm{C}$, the uptake of nanoparticles by HMVECS occurred as early as $10 \mathrm{~min}$ after the exposure, and the particles were localized within the cytoplasm of the cells. Approximately, 60\% of the cells engulfed the nanoparticles within $30 \mathrm{~min}$ after the stimulation (data not shown). The iron nanoparticles were gradually expelled out of the cells, with only $10 \%$ of the cells retaining the nanoparticles after $1 \mathrm{~h}$ stimulation (data not shown). The results demonstrate that the uptake of iron nanoparticles by HMVECs is both efficient and dynamic. 
A

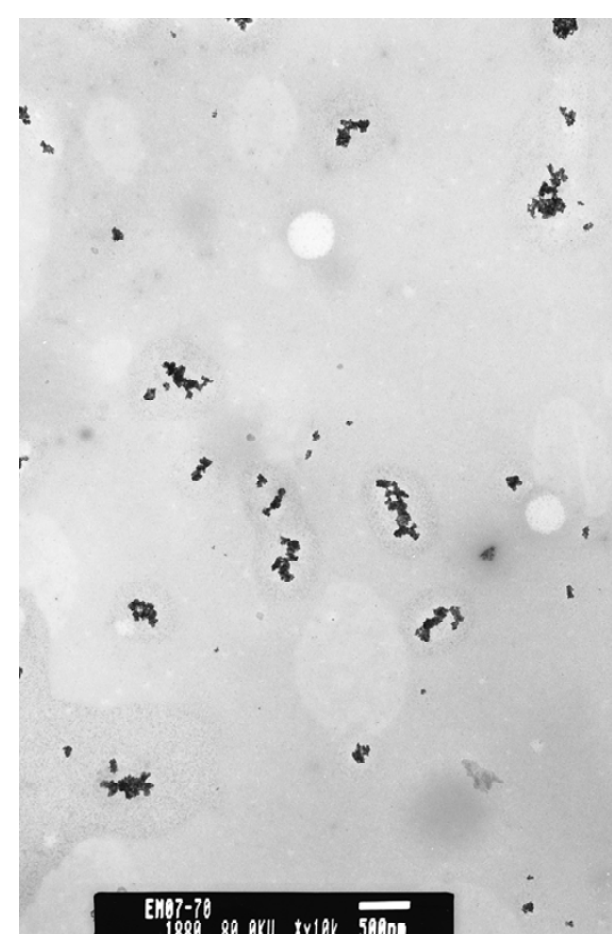

C
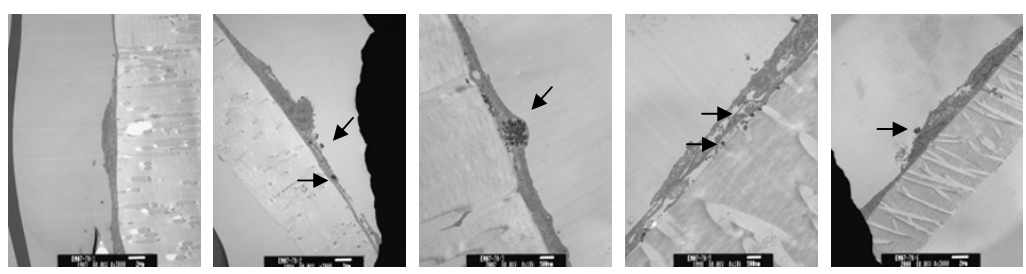

Time

$10 \mathrm{~min}$

30 min

$1 \mathrm{~h}$

$5 \mathrm{~h}$

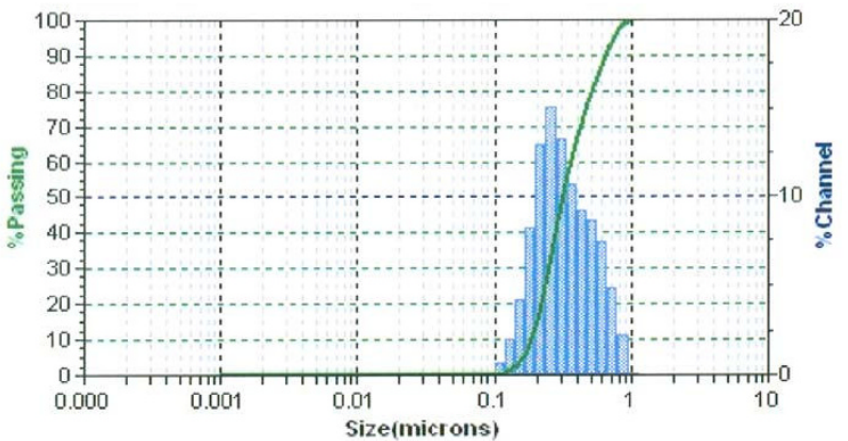

Figure I

Size distribution and cell uptake of iron nanoparticles. A, TEM micrograph of iron nanoparticles in $0.1 \%$ FBS cell culture media at the concentration of $50 \mu \mathrm{g} / \mathrm{ml}$. B, Dynamic light scattering measurements of iron nanoparticles in $0.1 \%$ FBS cell culture media at the concentration of $50 \mu \mathrm{g} / \mathrm{ml}$. C, TEM micrograph of iron nanoparticle uptake by HMVECs. HMVECs were stimulated with $50 \mu \mathrm{g} / \mathrm{ml}$ iron nanoparticles for different periods of time ranging from 10 minutes to 5 hours as indicated. The arrows indicate the location of iron nanoparticles. Each TEM micrograph represents one HMVEC.

\section{Iron nanoparticles induce an increase in permeability of HMVECs}

The changes in endothelial cell permeability not only play a major role in the pathogenesis of cardiovascular diseases, inflammation and cancer, but also have a critical effect on drug delivery to underlying cells, tissues, and organs [12]. We investigated whether exposure to iron nanoparticles would induce an increase in endothelial cell permeability. These results using confocal microscopy image analysis show that the unstimulated HMVECs were attached to each other tightly with no significant intercellular gaps in the HMVEC monolayer (Figure 2A1). However, upon exposure to iron nanoparticles, the confluent monolayer was pulled apart and the cells were separated from each other to form intercellular gaps, which is a hallmark of cell permeability increase [3]. The permeability increase occurred as early as $10 \mathrm{~min}$ after the exposure and persisted up to $5 \mathrm{~h}$ (Figure 2A2-5). The increase in permeability peaked around $30 \mathrm{~min}$ after the exposure (Figure 2A3). To further prove iron nanoparticle-induced HMVEC 
A
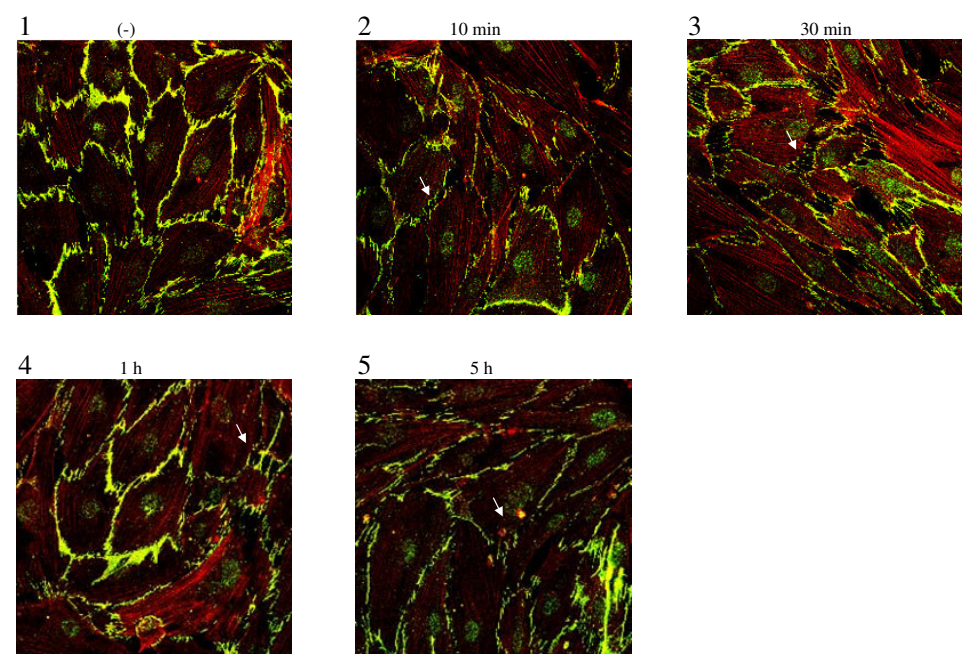

B

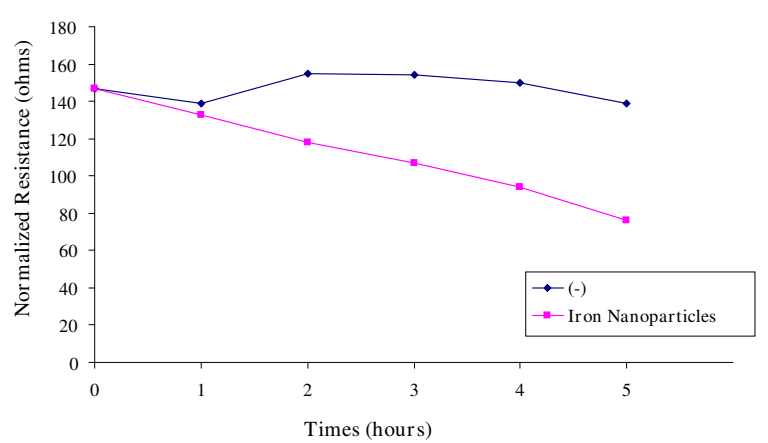

$\mathrm{C}$

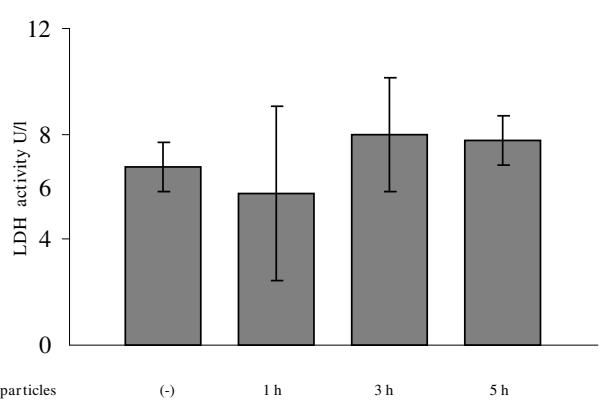

\section{Figure 2}

Iron nanoparticles induce endothelial cell permeability in HMVECs. A. HMVECs were grown to a confluent monolayer on coverslides and serum-starved overnight. The cells were exposed to $50 \mu \mathrm{g} / \mathrm{ml}$ iron nanoparticle for different periods of time as indicated. After exposure, the cells were fixed, permeabilized, and stained with VE-cadherin (green color) and actin filaments (red color). A Zeiss confocal microscope was applied to take the images. Each image is an overlay of two different stains. Arrows indicate the gaps. B. HMVECs were grown to a confluent monolayer on gold microelectrodes and serumstarved overnight. The cells were treated with $50 \mu \mathrm{g} / \mathrm{ml}$ iron nanoparticles, followed by measuring the transendothelial resistance (TER) for 5 hours. The results shown are representative of 3 independent experiments. C. Exposure of HMVECs to 50 $\mu \mathrm{g} / \mathrm{ml}$ iron nanoparticles does not induce cytotoxicity. HMVECs were exposed to $50 \mu \mathrm{g} / \mathrm{ml}$ for different periods of time as indicated. At the end of each exposure, the cell culture media was collected and measured for lactate dehydrogenease (LDH) activities. Values given are means $\pm S D$ (t-test, $n=5, p>0.19$ ). 
permeability, we measured transendothelial electrical resistance (TER) across HMVEC monolayer with an electric cell-substrate impedance sensor (ECIS). Our results demonstrate that exposure of HMVECs to iron nanoparticles decreased electrical resistance (Figure 2B), indicating endothelial monolayer barrier compromise. Our dosedependent ECIS assays demonstrate that iron nanoparticles have an ability to induce endothelial permeability at the concentrations ranging from $12.5 \mu \mathrm{g} / \mathrm{ml}$ to $100 \mu \mathrm{g} / \mathrm{ml}$ (data not shown). To rule out the possibility that iron nanoparticle may induce endothelial permeability change due to cytotoxicity-related cell damage, the LDH (lactate dehydrogenase) release assays were performed. Our results indicate that at the concentration of $50 \mu \mathrm{g} / \mathrm{ml}$, iron nanoparticles did not significantly induce cytotoxicity within 5 hours of incubation (Figure 2C). Taken together, these results demonstrate that iron nanoparticles have an ability to induce an increase in cell permeability in HMVECs.

\section{Iron nanoparticles induce cell permeability through microtubule remodeling in HMVECs}

We next examined the underlying molecular mechanisms leading to an increase in permeability upon iron nanoparticle stimulation. Cytoskeleton protein microtubules are the major structural proteins involved in endothelial cell permeability through the dynamic remodeling processes $[13,14]$. This study sought to investigate the importance of microtubule remodeling in iron nanoparticle-induced cell permeability in HMVECs. Here, we first identified whether iron nanoparticles had an ability to induce microtubule remodeling in HMVECs. As shown in figure $3 \mathrm{~A}$, the cells treated with iron nanoparticles exhibited a significant remodeled microtubule structure. In normal HMVECs, the acetylated microtubules, a stabilized form of microtubules, formed network-fiber structures surrounding the nuclear area. However, upon exposure to iron nanoparticles, the network-fiber structures were disrupted to form dotted structures distributed evenly throughout the cells, and the amount of acetylated microtubules was also increased. Next, we investigated the effects of iron nanoparticles on acetylated microtubules with immunoblotting analysis. As shown in figure 3B, iron nanoparticles induced an increase in acetylated microtubules as early as $10 \mathrm{~min}$ after the treatment. The increase in acetylated microtubules was maintained up to $1 \mathrm{~h}$. These results demonstrate that iron nanoparticle exposure promotes microtubule polymerization and altered distribution in HMVECs.

We then determined the involvement of microtubule remodeling in iron nanoparticle-induced cell permeability with different kinds of microtubule inhibitors: nocodazole and paclitaxel. Nocodazole depolymerizes microtubules and paclitaxel polymerizes microtubules.
The results show that the pretreatment with paclitaxel increased iron nanoparticle-induced cell permeability whereas the pretreatment with nocodazole decreased the permeability (Figure 3C). Taken together, these results support the hypothesis that iron nanoparticles induce endothelial cell permeability in HMVECs through the stabilization of microtubule structures.

\section{Iron nanoparticles induce cell permeability through the production of ROS in HMVECs}

Accumulating evidence strongly suggest that many materials at the nanoparticle size have the ability to induce the production of ROS [15]. We sought to determine if the production of ROS is involved in iron nanoparticleinduced cell permeability. First, we examined whether iron nanoparticle exposure stimulated ROS production in HMVECs with flow cytometry analysis. As shown in figure $4 \mathrm{~A} 1$, iron nanoparticle exposure significantly increased ROS production in 1 hour, compared to the unexposed cells. To determine the specificity of ROS production, the cells were pretreated with catalase, a ROS scavenger, followed by iron nanoparticle exposure. The results showed that catalase pretreatment blocked iron nanoparticleinduced ROS in HMVECs (Figure 4A1). We also exposed the cells to $500 \mu \mathrm{M} \mathrm{H}_{2} \mathrm{O}_{2}$ to set it as a positive control. Our results demonstrated that $\mathrm{H}_{2} \mathrm{O}_{2}$ exposure induced the production of ROS in HMVECs, which was significantly inhibited by catalase (Figure 4A1). To exclude the possibility that iron nanoparticles may generate ROS intrinsically, we measured the production of ROS in cell free systems. Our results found that iron nanoparticles were unable to produce ROS in cell-free systems (cell culture media without HMVECs); however the positive control, $\mathrm{H}_{2} \mathrm{O}_{2}$, was able to produce significant amount of ROS in the same systems (Figure 4A2). These results demonstrate that iron nanoparticle-induced ROS production in HMVECs is generated from the cell oxidative stress response. We then investigated the importance of ROS production in iron nanoparticle-induced cell permeability with a ROS scavenger catalase. As shown in figure 4B1 and $4 \mathrm{~B} 2$, pretreatment of cells with catalase inhibited iron nanoparticle-induced dotted microtubule structures and microtubule distribution, and inhibited cell permeability as well, indicating that ROS are involved in the regulation of iron nanoparticle-induced microtubule remodeling and cell permeability. This study further confirmed the effect of ROS production on microtubule remodeling by immunoblotting analysis. As shown in figure $4 \mathrm{C}$, the pretreatment of cells with catalase significantly attenuated iron nanoparticle-induced acetylated microtubule formation. 
A

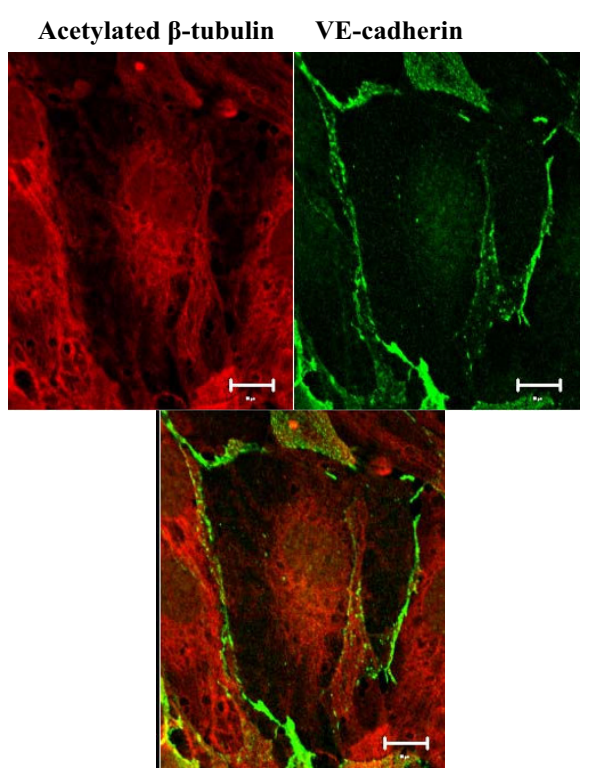

$(-)$

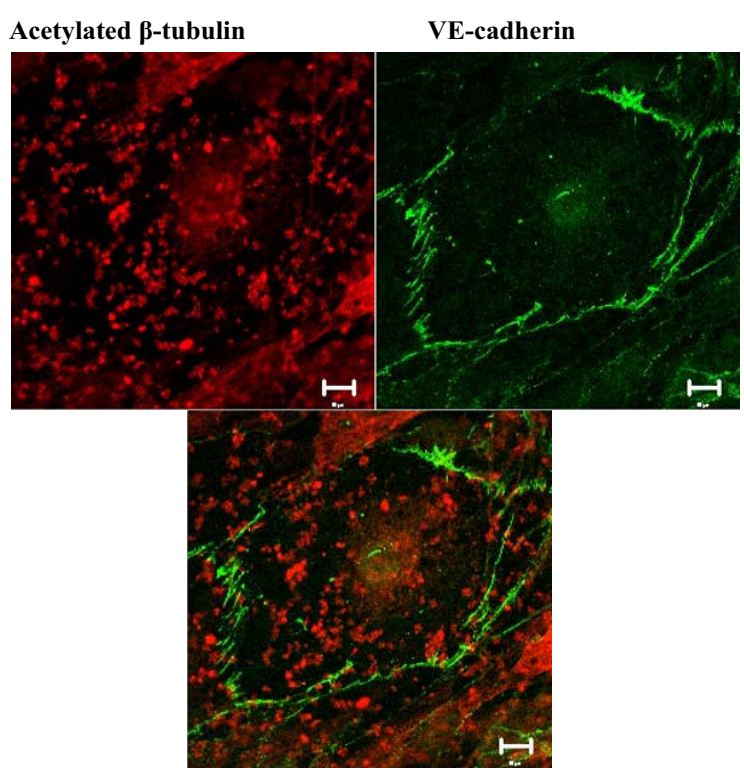

Iron nanoparticles

B
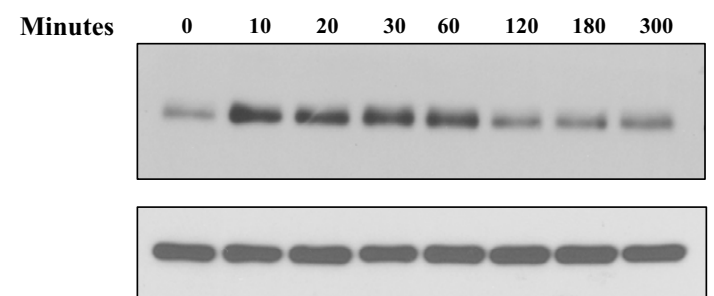

C

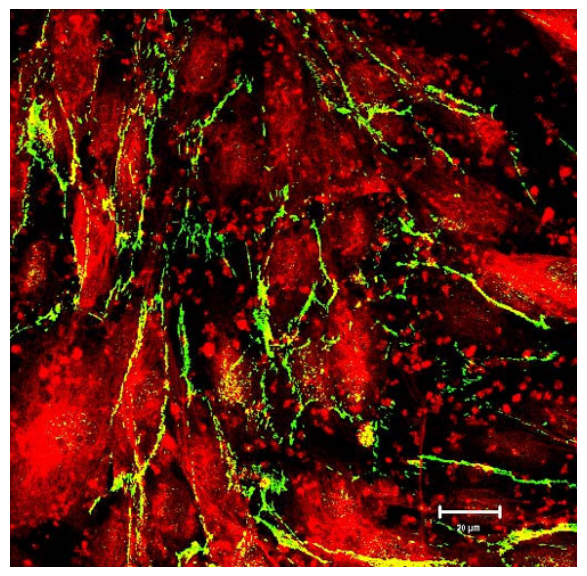

Iron nanoparticles/paclitaxel
Acetylated $\alpha-$ tubulin

Total $\alpha$-tubulin

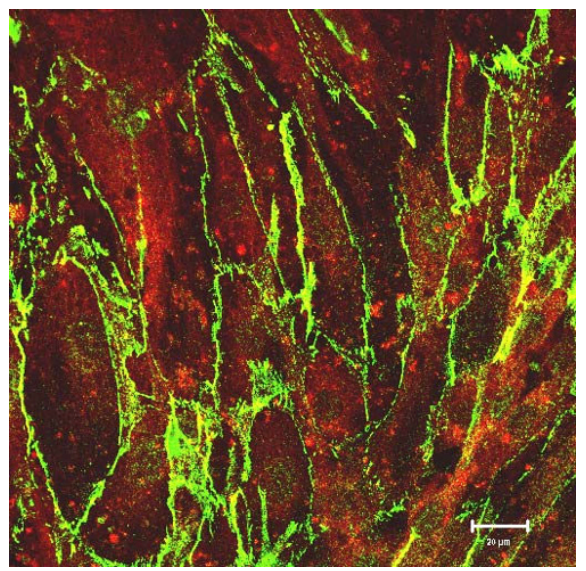

Iron nanoparticles/nocodazole

Figure 3 (see legend on next page) 
Figure 3 (see previous page)

Iron nanoparticles induce cell permeability through microtubule remodeling in HMVECs. A, Iron nanoparticles induce microtubule remodeling and redistribution. HMVECs were grown on coverslips and serum-starved overnight. Iron nanoparticles $(50 \mu \mathrm{g} / \mathrm{ml})$ were used to stimulate the cells for $30 \mathrm{~min}$. After exposure, the cells were fixed and stained for acetylated $\beta$-tubulin (red color) and VE-cadherin (green color). A Zeiss confocal microscope was applied to take the images. The bottom panels of each image are overlays of two different stains. The size of the scale bar is $20 \mu \mathrm{m}$. B, A time course of iron nanoparticle-induced microtubule stabilization. HMVECs were grown to a confluent monolayer and serum-starved overnight. The cells were exposed to $50 \mu \mathrm{g} / \mathrm{ml}$ iron nanoparticles for different periods of time as indicated. After exposure, the cells were lysed. The lysates were resolved on SDS-PAGE gel, and anti-acetylated $\alpha$-tubulin antibody was used to detect acetylated $\alpha$-tubulin. C, The monolayer HMVECs were pretreated with either $100 \mathrm{nM}$ paclitaxel or $10 \mathrm{nM}$ nocodazole for one hour as indicated, followed by exposure to $50 \mu \mathrm{g} / \mathrm{ml}$ iron nanoparticles for $30 \mathrm{~min}$. The cells were fixed and stained for acetylated $\alpha$-tubulin (red color) and VE-cadherin (green color). A Zeiss confocal microscope was applied to take the images. Each image is an overlay of two different stains. The size of the scale bar is $20 \mu \mathrm{m}$.

\section{Iron nanoparticles induce HMVEC permeability via GSK-} $\mathbf{3} \beta$ signaling pathways

The inhibition of GSK-3 $\beta$ (phosphorylation at serine 9) plays a major role in regulating microtubule stabilization [16]. This study investigated if GSK-3 $\beta$ is involved in iron nanoparticle-induced microtubule stabilization and cell permeability in HMVECs. As shown in figure 5A, iron nanoparticles induced serine-9 phosphorylation of GSK$3 \beta$ within $10 \mathrm{~min}$ after the treatment, and the increase in the phosphorylation was maintained up to $2 \mathrm{~h}$. We then explored the activities of Akt, an upstream kinase of GSK$3 \beta$, upon iron nanoparticle exposure. It was found that the pattern of Akt phosphorylation (activation) was the same as that of GSK-3 $\beta$ (Ser-9) phosphorylation (Figure $5 \mathrm{~A})$. The results also showed that iron nanoparticleinduced phosphorylation of both GSK-3 $\beta$ (Ser-9) and Akt was dramatically attenuated by the pretreatment with a PI3K inhibitor, LY294002 (Figure 5B). These results indicate that iron nanoparticles have an ability to induce the inhibition of GSK-3 $\beta$ through the PI3K/Akt signaling pathway.

We then determined the role of ROS production in iron nanoparticle-induced GSK-3 $\beta$ inhibition and Akt activation. As shown in figure $5 \mathrm{C}$, hydrogen peroxide alone increased the phosphorylation of both GSK-3 $\beta$ (Ser-9) and Akt (Ser -473) in a manner similar to that of iron nanoparticle exposure. When the cells were treated with iron nanoparticles plus hydrogen peroxide, the induction of GSK-3 $\beta$ (Ser-9) and Akt (Ser-473) phosphorylation was enhanced compared with either treatment alone. Furthermore, the pretreatment of cells with catalase attenuated iron nanoparticle-induced phosphorylation of both GSK$3 \beta$ (Ser 9) and Akt (Ser 473) (Figure 5C). These results indicate that ROS production plays a regulatory role in iron nanoparticle-induced GSK-3 $\beta$ inhibition and Akt activation.

Lastly, this study sought to determine the regulatory roles of GSK-3 $\beta$ inhibition in iron nanoparticle-induced micro- tubule remodeling and cell permeability by using a pharmacological inhibitor of GSK-3 $\beta$, GSK-3 $\beta$ inhibitor I. These results demonstrate that the pretreatment with GSK-3 $\beta$ inhibitor I enhanced iron nanoparticle-induced microtubule remodeling and cell permeability (Figure $5 \mathrm{D} 1$ and 5D2). These results suggest that GSK-3 $\beta$ may be involved in regulating iron nanoparticle-induced microtubule remodeling and cell permeability in HMVECs.

\section{Discussion}

The endothelial cells line the luminal surface of blood vessels to form a semi-permeable barrier to regulate vascular tone, blood fluidity, angiogenesis, and extravasation of blood components and other substances [3,17]. The changes in this semi-permeable barrier are critical in controlling the passage of macromolecules and fluid from the blood circulation into tissues, which is a key molecular process for drug delivery, as well as for the pathogenesis of inflammatory diseases, cardiovascular diseases, lung injury, carcinogenesis [3,17]. The endothelial semi-permeable barrier controls the transfer of many soluble and insoluble substances via two pathways: transcellular and paracellular pathways [3]. The transcellular pathway transports many substances via transcytosis in vesicle carriers whereas the paracellular pathway transfers substances through tightly linked inter-endothelial junctions. The paracellular pathway-mediated permeability is maintained by an equilibrium between cytoskeleton-generated contractile force and cell-cell junction and contactinduced adhesive force [18]. Any shift in this equilibrium will results in the opening and closing of paracellular pathways to affect the transport of macromolecules and drugs [18]. The unperturbed endothelium paracellular pathway can only allow transport of molecules with a radius of less than $3 \mathrm{~nm}$ to move passively across the barrier [3]. However, in response to stimulation or pathologic conditions, the paracellular pathway becomes leaky, opening inter-endothelial junctions to form the gaps between endothelial cells to allow the translocation of larger molecules [19]. Previous studies reported that nan- 


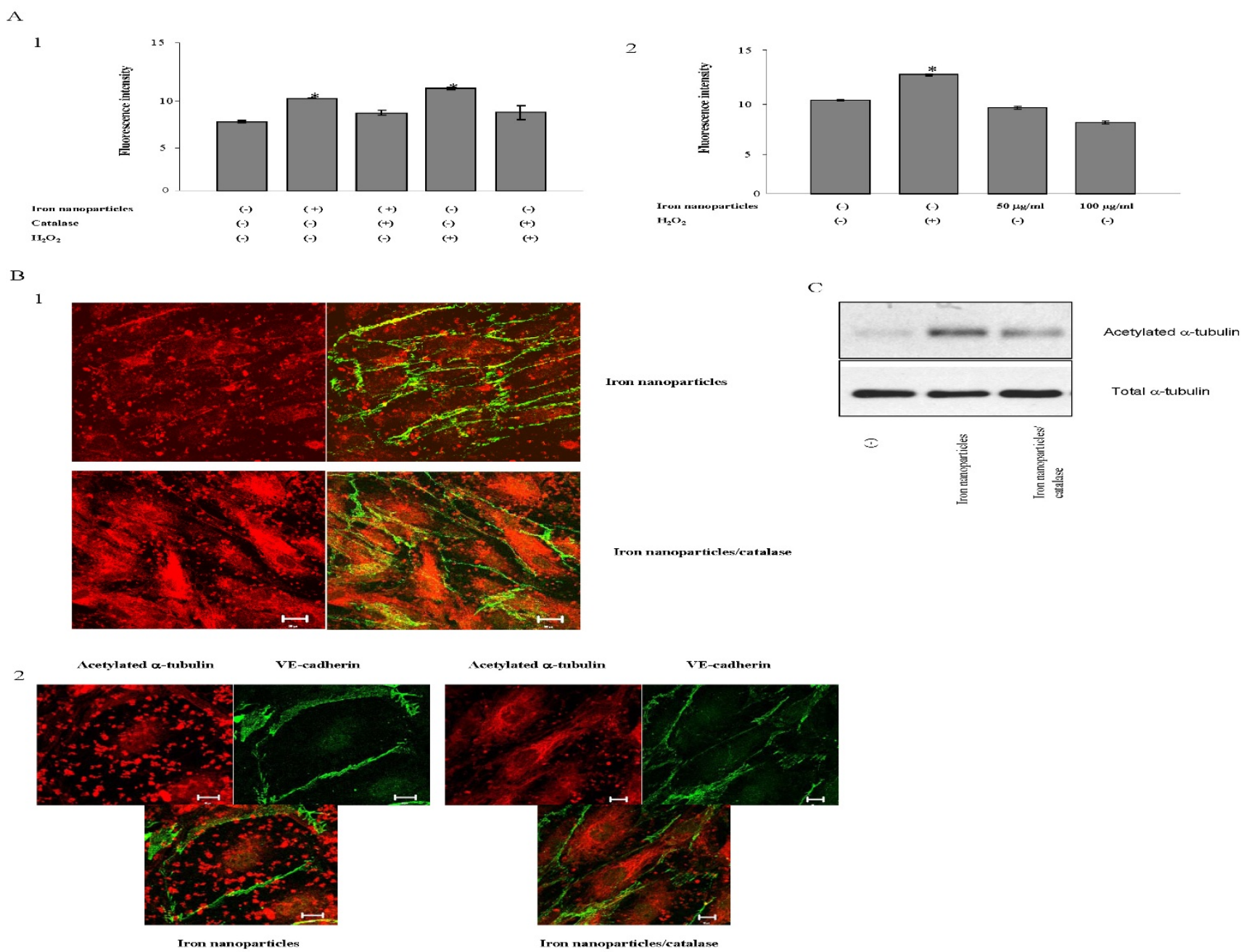

Figure 4

ROS production is involved in iron nanoparticle-induced cell permeability. A, Iron nanoparticles induce the production of ROS in HMVECs. I. Iron nanoparticles induce the production of ROS in HMVECs. The monolayer HMVECs were pretreated with $10 \mu \mathrm{M} \mathrm{CM}-\mathrm{H}_{2}$ DCFDA, as well as 10,000 unit catalase as indicated, for one hour, followed by exposure to $50 \mu \mathrm{g} /$ $\mathrm{ml}$ iron nanoparticles or $500 \mu \mathrm{M} \mathrm{H}_{2} \mathrm{O}_{2}$ for another hour as indicated. After the stimulation, the cells were collected and analyzed by a flow cytometry. Values given are means $\pm S D\left(t-t e s t, n=5\right.$, $\left.*_{p}<0.01\right)$. 2. Iron nanoparticles do not induce the production of ROS in cell-free system. The hydrolyzed CM- $\mathrm{H}_{2}$ DCF-DA was mixed with $50 \mu \mathrm{g} / \mathrm{ml}$ iron nanoparticles, $100 \mu \mathrm{g} / \mathrm{ml}$ iron nanoparticles, or I mM $\mathrm{H}_{2} \mathrm{O}_{2}$ as indicated, followed by the fluorescence measurements using a cytoflour series 4000 plate reader. Values given are means $\pm S D$ (t-test, $n=5$, $*_{p}<0.05$ ). B, Catalase pretreatment inhibits iron nanoparticle-induced microtubule remodeling and permeability in HMVECs. HMVECs were pretreated with 10,000 units $/ \mathrm{ml}$ of catalase for one hour, followed by exposure to $50 \mu \mathrm{g} / \mathrm{ml}$ iron nanoparticles for 30 minutes. The cells were fixed and stained for acetylated $\alpha$-tubulin (red color) and VE-cadherin (green color). A Zeiss confocal microscope was applied to take the images. The size of the scale bar is $20 \mu \mathrm{m}$. I. Images of microtubule remodeling and cell permeability. The right panels are an overlay of two different stains. 2. Images of microtubule remodeling for the individual cells. C, Catalase pretreatment inhibits iron nanoparticle-induced microtubule stabilization. HMVECs were pretreated with 10,000 units $/ \mathrm{ml}$ catalase for one hour, followed by the exposure to $50 \mu \mathrm{g} /$ $\mathrm{ml}$ iron nanoparticles for one hour. The cells were lysed, and the lysates were resolved with 8\% SDS-PAGE gel. An antiacetylated $\alpha$-tubulin antibody was applied to detect the expression of acetylated $\alpha$-tubulin.

oparticles are able to across the semi-permeable barrier via transcellular pathways [20]. However, little is known about the effects of nanoparticles on endothelial paracellular pathways. In this study, we demonstrate that iron nanoparticle stimulation induced an increase in cell permeability in vitro, i.e., the formation of gap structures between endothelial cells in a confluent endothelial monolayer. This indicates that the exposure to iron nanoparti- 
A

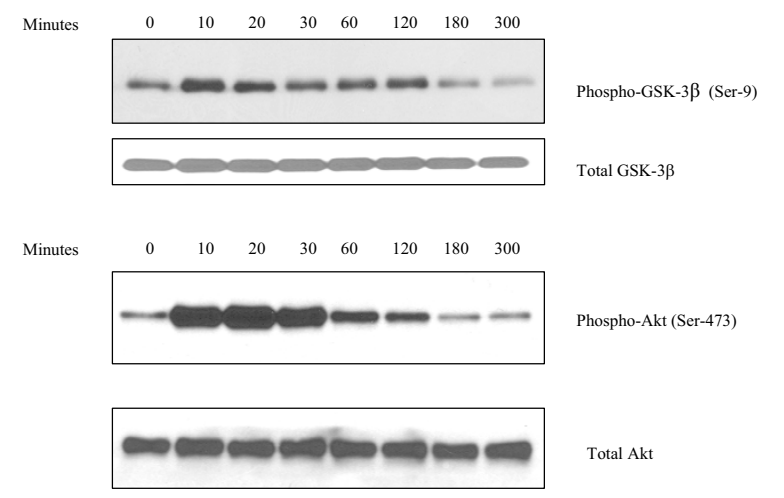

B

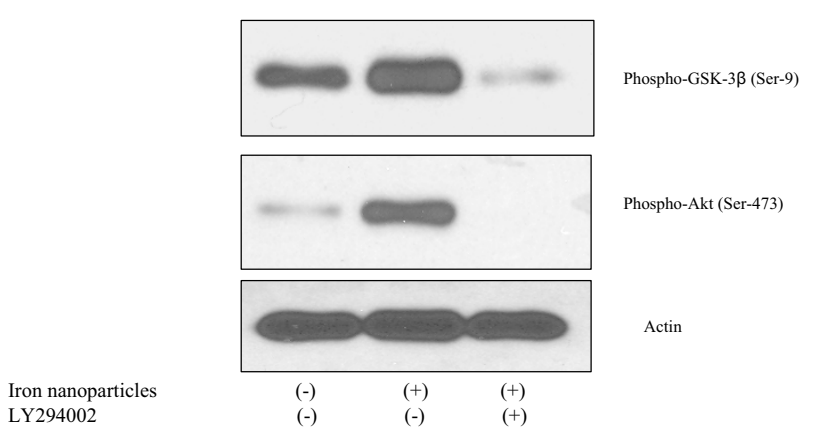

C

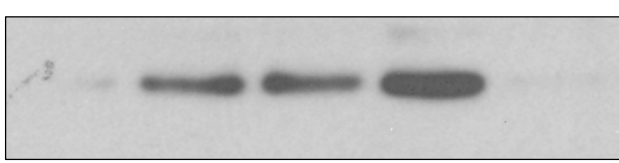

Phospho-GSK-3 $\beta($ Ser-9)

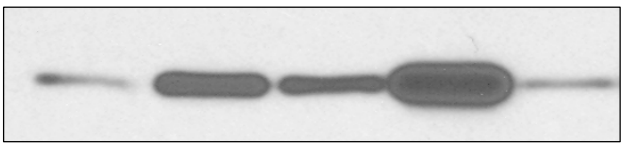

Phospho-Akt (Ser-473)

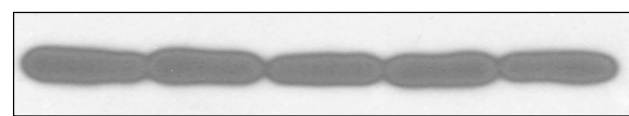

Actin

Iron nanoparticles

$\mathrm{H}_{2} \mathrm{O}_{2}$

$\mathrm{H}_{2} \mathrm{O}_{2}$
Catalase

$\begin{array}{ll}(-) & (+) \\ (-) & (-) \\ (-) & (-)\end{array}$

$\begin{array}{lll}(-) & (+) & (+) \\ (+) & (+) & (-) \\ (-) & (-) & (+)\end{array}$

(1)

D

1

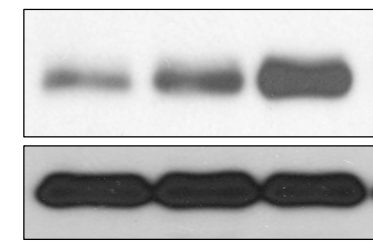

$\begin{array}{lll}(-) & (+) & (+) \\ (-) & (-) & (+)\end{array}$

2

Acetylated $\alpha$-tubulin

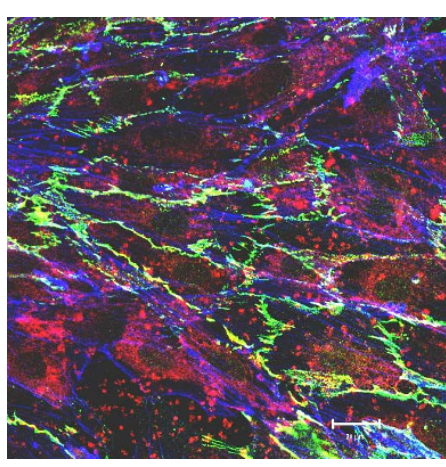

Iron nanoparticles

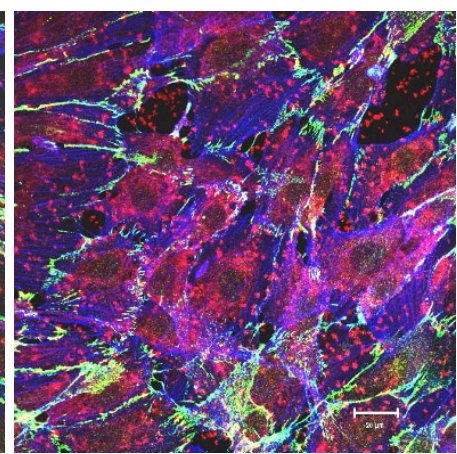

Iron nanoparticles/ GSK-3 $\beta$ inhibitor I

Figure 5 (see legend on next page) 
Figure 5 (see previous page)

GSK-3 $\beta$ signaling pathways are involved in iron nanoparticle-induced endothelial cell permeability. A, Iron nanoparticle treatment induces the inhibition of GSK-3 $\beta$ and the activation of Akt. HMVECs were grown to a confluent monolayer and serum-starved overnight. The cells were exposed to $50 \mu \mathrm{g} / \mathrm{ml}$ iron nanoparticles for different periods of time as indicated. After the stimulation, the cells were lysed. The lysates were resolved on SDS-PAGE gel, followed by probing with different antibodies as indicated. B, PI3K is involved in iron nanoparticle-induced Akt activation and GSK-3 $\beta$ inhibition. HMVECS were pretreated with $10 \mu M$ LY294002, a PI3K inhibitor, for one hour, and then exposed to $50 \mu g / \mathrm{ml}$ iron nanoparticles for 30 minutes, followed by Western blot analysis. C, ROS production is involved in iron nanoparticle-induced Akt activation and GSK-3 $\beta$ inhibition. HMVECs were pretreated with either $200 \mu \mathrm{M}$ hydrogen peroxide $\left(\mathrm{H}_{2} \mathrm{O}_{2}\right)$ or 10,000 units/ml catalase for one hour, and then exposed to $50 \mu \mathrm{g} / \mathrm{ml}$ iron nanoparticles for $30 \mathrm{~min}$, followed by Western blot analysis. D, The inhibition of GSK-3 $\beta$ enhances iron nanoparticle-induced microtubule remodeling and cell permeability in HMVECs. HMVECs were pretreated with $5 \mu$ M GSK-3 $\beta$ inhibitor I for one hour, and then exposed to $50 \mu \mathrm{g} / \mathrm{ml}$ iron nanoparticles for 30 minutes, followed by Western blot analysis (I) and confocal microscopy analysis (2). Blue color stains for actin filaments, red color stains for acetylated $\alpha-$ tubulin, and green color stains for VE-cadherin. The size of the scale bar is $20 \mu \mathrm{m}$.

cles may be able to facilitate extravasation of macromolecules and drugs, as well as nanoparticle themselves, into surrounding tissues. The results obtained from this study provide a new insight on the effects of nanoparticles on vascular transport of drugs and macromolecules.

The concentration $(50 \mu \mathrm{g} / \mathrm{ml})$ of iron nanoparticles applied in this manuscript is relevant to the dosages employed in current clinical trials. Human imaging in central nervous system and in carotid atherosclerotic plague utilized iron nanoparticles at $45 \mu \mathrm{mol} \mathrm{Fe} / \mathrm{kg}$ for magnetic resonance imaging [21], which is about the concentration of $70 \mu \mathrm{g} / \mathrm{ml}$ (at average $50 \mathrm{~kg}$ human weight and $5000 \mathrm{ml}$ human blood volume). Rat clinical trials for magnetic resonance imaging injected iron nanoparticles via intravenous injection at the dose of $5 \mathrm{mg} \mathrm{Fe} / \mathrm{kg}$ [22], which is about the concentration of $66 \mu \mathrm{g} / \mathrm{ml}$ (at average $200 \mathrm{~g}$ rat weight and $15 \mathrm{ml}$ rat blood volume). Therefore, our concentration $(50 \mu \mathrm{g} / \mathrm{ml})$ of iron nanoparticles is achievable in the circulation. The studies of iron nanoparticle pharmacokinetics and biodistribution demonstrated that the high doses of iron nanoparticles are needed to reach deep compartments of bodies in clinical imaging experiments [21].

The cellular uptake profiling shows that the peak of uptake occurs within $30 \mathrm{~min}$ of the stimulation and only $10 \%$ of the cells still retain iron nanoparticles after one hour of exposure. However, the alteration of signaling transduction pathway are maintained for almost two hours following exposure to iron nanoparticles, and both our confocal microscope analysis and ECIS assays show that iron nanoparticle-induced permeability lasts at least 5 hours after the stimulation. There results indicate that exposure of HMVECs to iron nanoparticles induces a prolong alteration of endothelial monolayer barrier function.

The unique features of nanoparticles are small particle size and large surface area, which exposes atoms or mole- cules on the particle surface instead of covering them within the interior of the material [15]. Accumulating evidence shows that nanoparticle-induced ROS oxidant stress response is the major mechanism for the induction of various biological effects [15,23]. At the low basal level, ROS is involved in regulating normal cell functions; however, at a higher abnormal level, ROS induce cell injury and death [24]. In this study, it was found that the exposure to iron nanoparticles induces the production of ROS in HMVECs. Furthermore, we found that the addition of $\mathrm{H}_{2} \mathrm{O}_{2}$ enhances iron nanoparticle-induced cell permeability whereas the elimination of ROS with catalase abrogates iron nanoparticle-induced cell permeability, demonstrating that the production of ROS is involved in iron nanoparticle-induced permeability. Our results regarding the roles of ROS in endothelial cell permeability are consistent with several published observations [24]. Numerous studies have shown that ROS-induced oxidant stress directly increases endothelial permeability $[6,24]$. The treatment of endothelial cell monolayers with ROS generators, xanthine/xanthine oxidase or glucose/glucose oxidase, increases endothelial cell permeability in a dose dependent manner $[25,26]$.

In this study, it was found that iron nanoparticle-induced ROS production may regulate cell permeability through the remodeling of microtubules in HMVECs. It was well established that microtubules remodeling is closely related to the changes in endothelial cell permeability $[3,19]$. However, it is controversial as to the mechanisms by which microtubule remodeling regulates cell permeability. Several previous studies showed that microtubules are involved in regulating both tumor necrosis factor- $\alpha$ and thrombin-induced endothelial permeability through destabilization (depolymerization) while some observations found that microtubules modulate cell permeability via stabilization (polymerization) in tumor cells $[14,27,28]$. In this study, it is demonstrated that iron nanoparticle exposure induces both polymerization and 
redistribution of microtubules through the production of ROS in HMVECs. Furthermore, it is demonstrated that ROS-mediated microtubule remodeling is involved in iron nanoparticle-induced endothelial cell permeability. The finding that iron nanoparticle exposure stimulates the activation of PI-3 kinase/Akt/GSK-3 $\beta$ signaling pathways further supports our observations of iron nanoparticleinduced microtubule remodeling. GSK- $3 \beta$ is a key kinase that regulates microtubule depolymerization via the phosphorylation of several microtubule-associated proteins [29]. Serine-9 phosphorylation of GSK-3 $\beta$ by Akt inhibits its activities, which abrogates GSK-3 $\beta$ 's ability to phosphorylate microtubule-associated protein and results in microtubule stabilization [29]. These results demonstrated that iron nanoparticle exposure induces the activation of Akt and inhibition of GSK-3 $\beta$ in a PI3-kinase dependent manner, and both our inhibitory and stimulatory assays strongly indicate that Akt/GSK-3 $\beta$ signaling pathways are involved in iron nanoparticle-induced cell permeability through ROS-mediated remodeling of microtubules.

Taken together, these results demonstrate that exposure to iron nanoparticle induces an increase in endothelial cell permeability through ROS oxidative stress- modulated microtubule remodeling (Figure 6). The findings from this study provide new insights on the effects of nanoparticles on vascular transport of macromolecules and drugs. Results provided here may have implications for understanding the bioactivity of engineered nanoparticles, which can inform potential applications in both nanomedicine and elucidate nanotoxicology in general.

\section{Methods \\ Reagents}

Cell culture medium EBM-2 was obtained from Lonza (Boston, MA). Fetal bovine serum was obtained from Atlanta Biologicals (Lawrenceville, GA). $\mathrm{Fe}_{2} \mathrm{O}_{3}$ nanoparticles were purchased from nGIMAT (Atlanta, GA). Acetylated-tubulin antibody, total tubulin antibody, actin antibody, catalase, hydrogen peroxide, EGF growth supplement, and hydrocortisone were from Sigma (St. Louis, $\mathrm{MO}$ ). Protease and phosphatase inhibitor cocktail was from Pierce (Rockford, IL). LY294002, GSK-3 $\beta$ inhibitor I, nocodazole and paclitaxel were obtained from Calbiochem (La Jolla, CA). Penicillin and Streptomycin antibiotics, 5-(and-6)-chloromethyl-2',7'dichlorodihydrofluorescein diacetate, acetyl ester (CM$\mathrm{H}_{2}$ DCFDA), secondary antibodies-conjugated with FITC, TRITC, and Cy5 were purchased from Invitrogen (Eugene, OR). Phospho-Akt (ser-473) and total Akt antibodies were from Cell Signaling Technology (Boston, MA). Phospho-GSK-3 $\beta$ (ser-9) and total GSK-3 $\beta$ antibodies were from Santa Cruz Biotechnology (Santa Cruz, CA). VE-

\section{Iron nanoparticles}
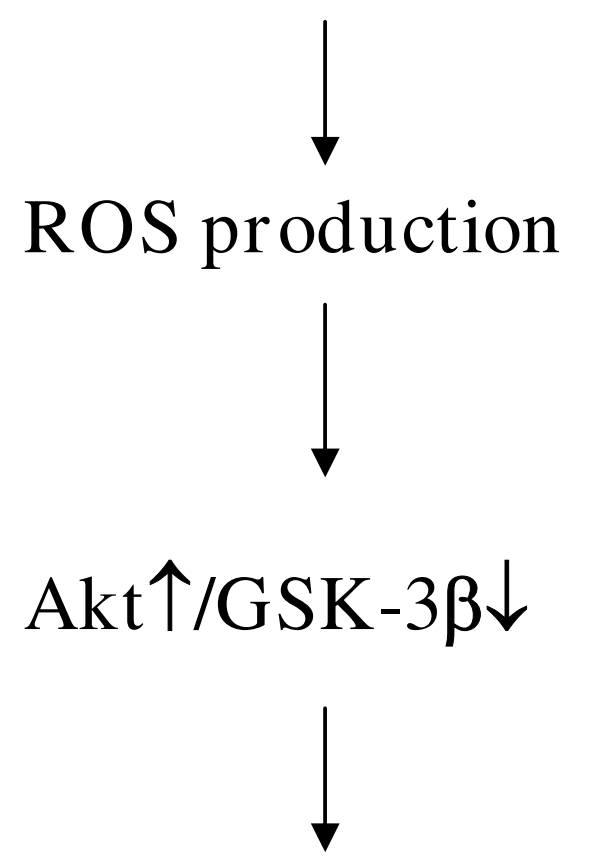

\section{Microtubule remodeling}

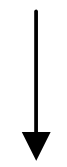

\section{Permeability}

\section{Figure 6}

Schematic representation of signal transduction from iron nanoparticle stimulation to cell permeability.

Cadherin antibody was purchased from Alexis (San Diego, CA).

\section{Cell culture}

The human microvascular endothelial cells (HMVECs) were a kind gift from Dr. Rong Shao (Biomedical Research Institute, Baystate Medical Center/University of Massachusetts at Amherst, Springfield, MA, USA). The cells were cultured according to the protocol described previously [11]. Briefly, HMVEC were grown in endothelial basal medium-2 (EBM-2) (Lonza, Boston MA) supplemented with $10 \%(\mathrm{v} / \mathrm{v})$ fetal bovine serum (FBS) (Atlanta Biologicals, Lawrenceville, GA), $100 \mathrm{U} / \mathrm{ml}$ penicillin and $10 \mu \mathrm{g} /$ 
$\mathrm{ml}$ streptomycin, $1 \mu \mathrm{g} / \mathrm{ml}$ of epidermal growth factor and $50 \mu \mathrm{g} / \mathrm{ml}$ hydrocortisone. The cells were maintained in an incubator at $37^{\circ} \mathrm{C}$ with $5 \% \mathrm{CO}_{2}$.

\section{Particles preparation and size measurements}

$\mathrm{Fe}_{2} \mathrm{O}_{3}$ nanoparticles were purchased from nGIMAT (Atlanta, GA). Their surface area was approximately 165 $\mathrm{m} 2 / \mathrm{g}$, the average powered particle size was $<10 \mathrm{~nm}$, and there were trace amounts of Lead and Bismuth potentially in the particles. The iron nanoparticles were suspended in $0.1 \%$ fetal bovine serum (FBS) cell culture media at a concentration of $2.5 \mathrm{mg} / \mathrm{ml}$. Once the nanoparticles were dispersed in $0.1 \%$ FBS cell culture media, the suspension was indirectly sonicated at $4{ }^{\circ} \mathrm{C}$ for 10 min with a HielscherUltrasound Technology Sonicator (UIS 259L) at amplitude $100 \%$ and cycle 1 . After the indirect sonication, the suspension was further directly sonicated at $4{ }^{\circ} \mathrm{C}$ for $5 \mathrm{~min}$ at a duty cycle setting of $10 \%$ and output of 5 with a Branson 450 Sonifier probe sonicator. The stock solution $(2.5$ $\mathrm{mg} / \mathrm{ml}$ ) of iron nanoparticles was kept at $4{ }^{\circ} \mathrm{C}$ and used within 2 weeks for the experiments. The working concentration of iron nanoparticle was $50 \mu \mathrm{g} / \mathrm{ml}$. Prior to being diluted to the working concentration, the stock solution was directly sonicated at $4^{\circ} \mathrm{C}$ for $1 \mathrm{~min}$ at the setting indicated above. The particle size was determined by both dynamic light scattering using Nanotrac 252 (Microtrac, Montgomeryville, PA) [30] and by a transmission electron microscope.

\section{Lactate dehydrogenase (LDH) assay}

The $\mathrm{LDH}$ release assays were measured using the $\mathrm{LDH}$ assay kit form Roche Diagnostics Inc. (Indianapolis, IN) according to the manufacturer instructions.

\section{ROS production in Cell-free system}

The measurements of ROS production in cell-free system were performed according to the previously published

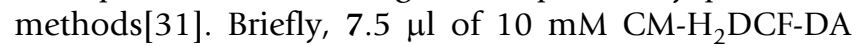
was chemically hydrolyzed to $\mathrm{CM}-\mathrm{H}_{2} \mathrm{DCF}$ in $1 \mathrm{ml}$ of 0.01 $\mathrm{N} \mathrm{NaOH}$ in dark for $30 \mathrm{~min}$ at the room temperature, followed by neutralizing with $0.5 \mathrm{ml}$ of $0.1 \mathrm{M}$ PBS (pH 7.4). The reaction mixture was freshly prepared by mixing 400 $\mu \mathrm{l}$ of the neutralized $\mathrm{CM}-\mathrm{H}_{2} \mathrm{DCF}, 1.6 \mathrm{ml}$ of EBM-2 medium ( $0.1 \%$ FBS), and 0.2 units of horse radish peroxidase (HRP) to obtain a final concentration of $10 \mu \mathrm{M} \mathrm{CM}$ $\mathrm{H}_{2}$ DCF. Then, $2 \mu \mathrm{l}$ of iron nanoparticle stock solution (25 $\mathrm{mg} / \mathrm{ml})$ or $2 \mu \mathrm{l}$ of $\mathrm{H}_{2} \mathrm{O}_{2}$ stock solution $(0.5 \mathrm{M})$ was added into $2 \mathrm{ml}$ of the reaction mixture to make a final concentration of $50 \mu \mathrm{g} / \mathrm{ml}$ iron nanoparticles or $500 \mu \mathrm{M} \mathrm{H}_{2} \mathrm{O}_{2}$, respectively. After 30 minute incubation, fluorescence generated from the oxidation of CM- $\mathrm{H}_{2}$ DCF to DCF was measured using a cytoflour series 4000 plate reader (PerSeptive Biosystems, Inc., Framingham, MA) at 485 nm excitation and 530 emission

\section{ROS measurements by flow cytometry}

ROS measurements by flow cytometry analysis were performed according to the methods described previously [32]. HMVECs were pretreated with $10 \mu \mathrm{M} \mathrm{CM}-\mathrm{H}_{2}$ DCFDA for $60 \mathrm{~min}$. After the pretreatment, the cell culture media was removed and replaced with the media containing iron nanoparticles $(50 \mu \mathrm{g} / \mathrm{ml})$ and $10 \mu \mathrm{M} \mathrm{CM}-\mathrm{H}_{2}$ DCFDA for further stimulation. After the stimulation, the cells were quenched on ice for $10 \mathrm{~min}$ then washed three times with ice-cold PBS before they were harvested by scrapping. The cells were fixed with $10 \%$ formaldehyde for $20 \mathrm{~min}$ at room temperature and then washed three times with PBS, followed by resuspension in $400 \mathrm{ml}$ of PBS. ROS measurements were carried out by a flow cytometry using FACSCalibur system (BD Biosciences, Rutherford, NJ) with a 488-nm excitation beam. The signals were obtained using a 530-nm band-pass filter for $\mathrm{CM}-\mathrm{H}_{2}$ DCFDA. Each measurement was based on the mean fluorescence intensity of 10,000 cells.

\section{Transendothelial electrical resistance}

The transendothelial electrical resistance (TER) was measured using electrical cell-substrate impedance sensing system (ECIS) (Applied Biophysics, Troy, NY) according to the published protocol [33]. Briefly, HMVECs were grown to confluent monolayer on ECIS culture ware and serumstarved overnight. The electrical resistance was measured on cells located on the small gold electrodes in each of the wells. The culture medium was the electrolyte. The small gold electrode covered by confluent HMVECs and a larger gold counter electrode were connected to a phase-sensitive lock-in amplifier. A constant current of $1 \mu \mathrm{A}$ was supplied by a $1-\mathrm{V}, 4,000-\mathrm{Hz}$ alternating current through a 1 $\mathrm{M} \Omega$ resistor. Changes in voltage between the small electrode and the large counter electrode were continuously monitored by the lock-in amplifier, stored, and then calculated as resistance.

\section{Immunofluorescence assay and Western blot analysis}

Immunofluorescence assays were performed according to the methods published previously [34]. Briefly, HMVECs were grown on coverslides. After treatment, cells were fixed and permeabilized, followed by labeling with the specific antibodies for the targeted proteins as well as immunofluorescence-conjugated secondary antibodies. The labeled coverslides were mounted to the slides with antifade reagent (Invitrogen, Eugene, OR). A Zeiss LSM 510 microscope was used to obtain images. Scale bars were generated and inserted by LSM software. Western blot analysis was performed according to the methods described previously [35]. Briefly, the cell lysates were resolved in $8 \%$ SDS-PAGE gel, and then transferred to PVDF membranes, followed by blotting with different antibodies for the individual targeted proteins. Horseradish peroxidase-conjugated secondary antibodies (GE 
Healthcare) were applied to visualize proteins using chemiluminescence.

\section{Transmission electron microscopy (TEM) of iron nanoparticles}

TEM of iron nanoparticles was performed according to previously published procedures [36]. Briefly, HMVECs were grown and stimulated in transwell tissue polycarbonate membrane polystyrene plates, and were then washed with ice cold PBS. The cells were fixed in Karnovsky's fixative $(2.5 \%$ glutaraldehyde $+3 \%$ paraformaldehyde in $0.1 \mathrm{M}$ sodium cacodylate, $\mathrm{pH} 7.4$ ), and then washed three times in $0.1 \mathrm{M}$ sodium cacodylate and postfixed in 1\% osmium tetra oxide, followed by washing with $0.1 \mathrm{M}$ sodium cacodylate and distilled water. The cells were dehydrated by sequential washings in $25 \%$, $50 \%$ and $100 \%$ ethanol then embedded in LX-112 (Ladd, Williston, VT). The ultrathin sections were stained with uranyl acetate and lead citrate and examined with a TEM (JEOL 1220, Tokyo, Japan). To measure the size distribution of iron nanoparticles in the cell culture medium, iron nanoparticles $(50 \mu \mathrm{g} / \mathrm{ml})$ were prepared as indicated above. An aliquot of this working solution was then dropped on a formvar-coated grid, let to dry then analyzed by transmission electron microscopy.

\section{Dynamic light scattering measurements}

Suspension of iron nanoparticles at $50 \mu \mathrm{g} / \mathrm{ml}$ was prepared in $0.1 \%$ FBS EBM-2 media. The iron nanoparticle suspension was sonicated with a probe sonicator (Branson Sonifier 450, $10 \mathrm{~W}$ continuous output) for $30 \mathrm{~min}$ and then vortexed for $1 \mathrm{~min}$, followed by measuring the particle size by dynamic light scattering using Nanotrac 252 (Microtrac, Montgomeryville, PA). During sonication, heat was dissipated by placing the samples on ice [30].

\section{Abbreviations}

HMVECS: human microvascular endothelial cells; ROS: reactive oxygen species; TEM: transmission electron microscopy; DLA: dynamic light scattering.

\section{Competing interests}

The authors declare that they have no competing interests.

\section{Authors' contributions}

PLA was substantially involved in conducting the experiments and drafting the manuscript. YQ is one of the project leaders and was substantially involved in the design of the project and drafting the manuscript. NLG, $\mathrm{RS}, \mathrm{XS}, \mathrm{VV}$, and VC participated in the design of the study and revised the manuscript. MP was involved in the particle preparation. DSB carried out the electron microscopy analysis. DP performed dynamic light scattering measure- ments. DCF is one of the project leaders and is involved in the design of the project.

\section{Disclaimer}

The findings and conclusions in this report are those of the author(s) and do not necessarily represent the views of the National Institute for Occupational Safety and Health.

\section{Acknowledgements}

Dr. Daniel C Flynn is supported by grants from the NIH (CA6073 I and RR I6440). Dr. Nancy Lan Guo is supported by grants from the NIH (R0ILM009500-0IA2 and RRI6440).

\section{References}

I. Corot C, Robert P, Idee JM, Port M: Recent advances in iron oxide nanocrystal technology for medical imaging. Adv Drug Deliv Rev 2006, 58( 1 4): |47|-1504.

2. Huber DL: Synthesis, properties, and applications of iron nanoparticles. Small 2005, I(5):482-50I.

3. Mehta $D$, Malik $A B$ : Signaling mechanisms regulating endothelial permeability. Physiol Rev 2006, 86(I):279-367.

4. Davda J, Labhasetwar V: Characterization of nanoparticle uptake by endothelial cells. Int J Pharm 2002, 233(I-2):5 I-59.

5. Munn LL: Aberrant vascular architecture in tumors and its importance in drug-based therapies. Drug Discov Today 2003, 8(9):396-403.

6. Houle F, Huot J: Dysregulation of the endothelial cellular response to oxidative stress in cancer. Mol Carcinog 2006, 45(6):362-367.

7. Shimada A, Kawamura N, Okajima M, Kaewamatawong T, Inoue $H$, Morita $\mathrm{T}$ : Translocation pathway of the intratracheally instilled ultrafine particles from the lung into the blood circulation in the mouse. Toxicol Pathol 2006, 34(7):949-957.

8. Buford MC, Hamilton RF Jr, Holian A: A comparison of dispersing media for various engineered carbon nanoparticles. Part Fibre Toxicol 2007, 4:6.

9. Raynal I, Prigent P, Peyramaure S, Najid A, Rebuzzi C, Corot C: Macrophage endocytosis of superparamagnetic iron oxide nanoparticles: mechanisms and comparison of ferumoxides and ferumoxtran-10. Invest Radiol 2004, 39(I):56-63.

10. Pisanic TR 2nd, Blackwell JD, Shubayev VI, Finones RR, Jin S: Nanotoxicity of iron oxide nanoparticle internalization in growing neurons. Biomaterials 2007, 28( I 6):2572-258I.

II. Shao R, Guo X: Human microvascular endothelial cells immortalized with human telomerase catalytic protein: a model for the study of in vitro angiogenesis. Biochem Biophys Res Commun 2004, 32 I (4):788-794.

12. Hu G, Place AT, Minshall RD: Regulation of endothelial permeability by Src kinase signaling: vascular leakage versus transcellular transport of drugs and macromolecules. Chem Biol Interact 2008, I 7 I(2): I77-189.

13. Birukova AA, Smurova K, Birukov KG, Usatyuk P, Liu F, Kaibuchi K, Ricks-Cord A, Natarajan V, Alieva I, Garcia JG, et al.: Microtubule disassembly induces cytoskeletal remodeling and lung vascular barrier dysfunction: role of Rho-dependent mechanisms. J Cell Physiol 2004, 20 I ( I):55-70.

14. Petrache I, Birukova A, Ramirez SI, Garcia JG, Verin AD: The role of the microtubules in tumor necrosis factor-alpha-induced endothelial cell permeability. Am J Respir Cell Mol Biol 2003, 28(5):574-58I.

15. Nel A, Xia T, Madler L, Li N: Toxic potential of materials at the nanolevel. Science 2006, 3 I I(576I):622-627.

16. Zumbrunn J, Kinoshita K, Hyman AA, Nathke IS: Binding of the adenomatous polyposis coli protein to microtubules increases microtubule stability and is regulated by GSK3 beta phosphorylation. Curr Biol 200 I, I I ( I):44-49.

17. Ding BS, Dziubla T, Shuvaev VV, Muro S, Muzykantov VR: Advanced drug delivery systems that target the vascular endothelium. Mol Interv 2006, 6(2):98-I 12.

18. Yuan SY: Protein kinase signaling in the modulation of microvascular permeability. Vascul Pharmacol 2002, 39(4-5):2 I3-223. 
19. Michel CC, Curry FE: Microvascular permeability. Physiol Rev 1999, 79(3):703-76I.

20. Moghimi SM, Hunter AC, Murray JC: Nanomedicine: current status and future prospects. Faseb / 2005, 1 9(3):3 II-330.

21. Corot C, Petry KG, Trivedi R, Saleh A, Jonkmanns C, Le Bas JF, Blezer E, Rausch M, Brochet B, Foster-Gareau P, et al:: Macrophage imaging in central nervous system and in carotid atherosclerotic plaque using ultrasmall superparamagnetic iron oxide in magnetic resonance imaging. Invest Radiol 2004, 39(10):619-625.

22. Briley-Saebo K, Bjornerud A, Grant D, Ahlstrom H, Berg T, Kindberg GM: Hepatic cellular distribution and degradation of iron oxide nanoparticles following single intravenous injection in rats: implications for magnetic resonance imaging. Cell Tissue Res 2004, 316(3):315-323.

23. Gwinn MR, Vallyathan V: Nanoparticles: health effects-pros and cons. Environ Health Perspect 2006, I I 4(12): 18|8-1825.

24. Lum $\mathrm{H}$, Roebuck KA: Oxidant stress and endothelial cell dysfunction. Am J Physiol Cell Physiol 200I, 280(4):C719-74I.

25. Holman RG, Maier RV: Oxidant-induced endothelial leak correlates with decreased cellular energy levels. Am Rev Respir Dis 1990, I 4 I(I): I34-I 40.

26. Shasby DM, Lind SE, Shasby SS, Goldsmith JC, Hunninghake GW: Reversible oxidant-induced increases in albumin transfer across cultured endothelium: alterations in cell shape and calcium homeostasis. Blood 1985, 65(3):605-614.

27. Birukova AA, Birukov KG, Smurova K, Adyshev D, Kaibuchi K, Alieva I, Garcia JG, Verin AD: Novel role of microtubules in thrombininduced endothelial barrier dysfunction. Faseb J 2004, I 8(1 5): | 879-1890.

28. Ivanov AI, McCall IC, Babbin B, Samarin SN, Nusrat A, Parkos CA Microtubules regulate disassembly of epithelial apical junctions. BMC Cell Biol 2006, 7:12

29. Salinas PC: Modulation of the microtubule cytoskeleton: a role for a divergent canonical Wnt pathway. Trends Cell Biol 2007, I 7(7):333-342.

30. Murdock RC, Braydich-Stolle L, Schrand AM, Schlager J], Hussain SM: Characterization of nanomaterial dispersion in solution prior to in vitro exposure using dynamic light scattering technique. Toxicol Sci 2008, I OI(2):239-253.

31. Cathcart R, Schwiers E, Ames BN: Detection of picomole levels of hydroperoxides using a fluorescent dichlorofluorescein assay. Anal Biochem 1983, I34(I): I I I- II6.

32. Chen JR, Shankar K, Nagarajan S, Badger TM, Ronis MJ: Protective effects of estradiol on ethanol-induced bone loss involve inhibition of reactive oxygen species generation in osteoblasts and downstream activation of the extracellular signal-regulated kinase/signal transducer and activator of transcription 3/receptor activator of nuclear factor-kappaB ligand signaling cascade. J Pharmacol Exp Ther 2008, 324(I):50-59.

33. Birukova AA, Birukov KG, Gorshkov B, Liu F, Garcia JG, Verin AD: MAP kinases in lung endothelial permeability induced by microtubule disassembly. Am J Physiol Lung Cell Mol Physiol 2005, 289(I):L75-84.

34. Qian Y, Liu KJ, Chen Y, Flynn DC, Castranova V, Shi X: Cdc42 regulates arsenic-induced NADPH oxidase activation and cell migration through actin filament reorganization. J Biol Chem 2005, 280(5):3875-3884.

35. Qian Y, Baisden JM, Westin EH, Guappone AC, Koay TC, Flynn DC: Src can regulate carboxy terminal interactions with AFAPII0, which influence self-association, cell localization and actin filament integrity. Oncogene 1998, I6(17):2 |85-2195.

36. Shvedova AA, Kisin ER, Mercer R, Murray AR, Johnson VJ, Potapovich Al, Tyurina YY, Gorelik O, Arepalli S, Schwegler-Berry D, et al.: Unusual inflammatory and fibrogenic pulmonary responses to single-walled carbon nanotubes in mice. Am J Physiol Lung Cell Mol Physiol 2005, 289(5):L698-708.

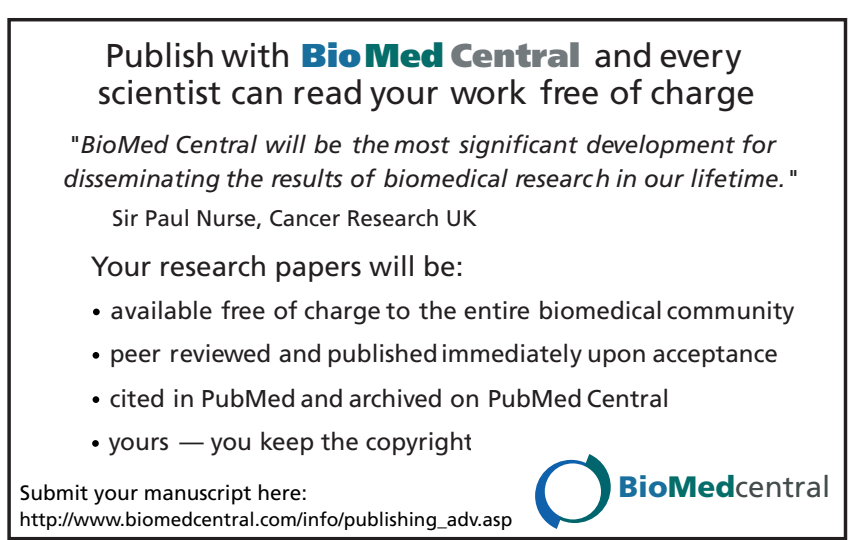

